\title{
Currents in
}

\section{Long Strait, Arctic Ocean}

\section{K. COACHMAN ${ }^{1}$ AND D. A. RANKIN ${ }^{2}$}

\begin{abstract}
During summer 1966, about 440 current measurements were made in Long Strait, which separates Wrangel Island from the Siberian mainland. This is the most comprehensive suite of current data available from the area and reveals significant information about the nature and generation of the currents. The semidiurnal tide wave of the Arctic Ocean, propagating eastward through the strait, gives rise to significant tidal oscillation of the currents primarily along the axis of the channel. The oscillation varies in amplitude with the semimonthly tidal inequality. The long-term mean flow through the strait is determined by the continuity requirements of the Chukchi Sea-East Siberian Sea system as it responds to the regional winds. When regional atmospheric pressure differences dictate southerly winds east of Wrangel Island and/or northerly winds to the west, there is a mean westbound flow through the strait, and vice versa. The surface-water layer and ice field respond more directly to local winds.
\end{abstract}

RÉSUMÉ. Les courants dans le détroit de Long, océan Arctique. Au cours de l'été de 1966, on a recueilli dans le détroit de Long, qui sépare l'île Wrangel de la Sibérie continentale, environ 440 mesures des courants. Cette suite de données actuelles est la plus complète dont on dispose pour la région et elle fournit une information très utile sur la nature et la genèse des courants. L'onde semi-quotidienne de marée de l'Arctique provoque, en se propageant vers l'Est à travers le détroit, une importante oscillation des courants, surtout dans l'axe du chenal. Cette oscillation varie en amplitude selon l'inégalité tidale semi-mensuelle. A long terme, le flux moyen dans le détroit est déterminé par la demande de continuité du système : mer de Tchoukotsk-mer de Sibérie orientale en correspondance avec les vents régionaux. Lorsque les différences régionales de la pression atmosphérique provoquent des vents du sud à l'Est de l'île Wrangel et/ou des vents du nord à l'Ouest de cette île, il se produit un flux vers l'ouest du détroit, et vice-versa. La couche d'eau de surface et le champ de glace sont plus directement sensibles aux vents locaux.

РЕЗЮМЕ. Морские Течения в пролпве Лонга. Летом 1966 года было произведено около 440 измерений морских течений в проливе Лонга, отделяющего остров Врангеля от сибирского материка. Эти измерения являются наиболее полным комплексом данных по течениям в проливе Јонга и дают пенную информацито об их образовании. Полусуточные приливы Ледовитого Океана, идушие в восточном направлении через пролив, вызывают значительные приливные колебания течений, преимущественно вдоль оси пролива. Амплитуда колебаний изменяется в зависимости от полумесячного приливного неравенства. Долгосрочное среднее течение через пролив определяется потребностями системы

Чукотского и Восточно-Сибирского морей по мере влияния региональных ветров. Когда перепады в региональном атмосферном давлении вызывают южные ветры восточнее острова Врангеля и (или же) северные ветры вападнее острова, среднее течение идет через пролив в эапалном направлении и наоборот. $\mathrm{Ha}$ движение поверхностного слоя воды и ледяного покрова влияют, преимущественно, местные ветры.

${ }^{1}$ Department of Oceanography, University of Washington, Seattle.

2Department of Oceanography, University of Washington, Seattle. Present address: U.S. Naval Torpedo Station, Keyport, Washington. 


\section{INTRODUCTION}

Long Strait is a broad channel between Wrangel Island and the northern coast of eastern Siberia, centred near $70^{\circ} \mathrm{N}$. latitude, $179^{\circ} \mathrm{E}$. longitude. It is approximately $120 \mathrm{~km}$. long and $140 \mathrm{~km}$. wide. The strait (Fig. 1) lies entirely on the broad, smooth continental shelf of this part of the Arctic Ocean, which has quite uniform depths of 40 to $50 \mathrm{~m}$.

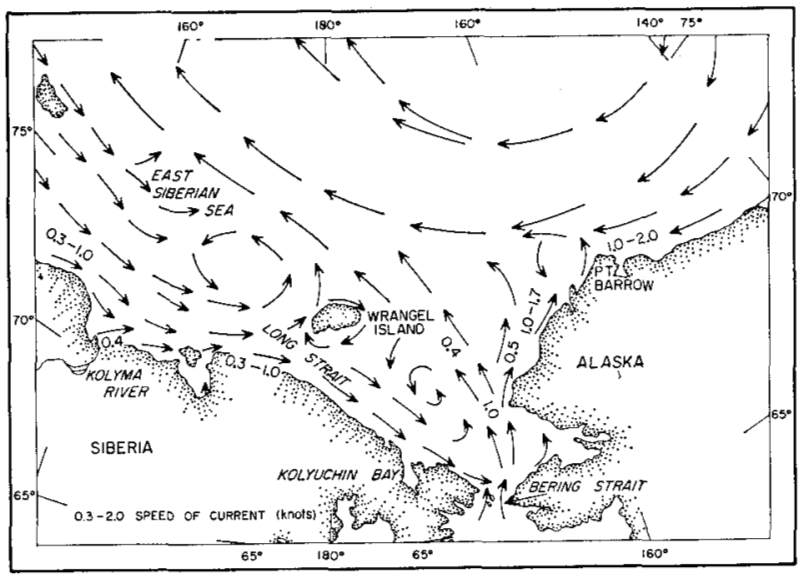

FIG. 1. Part of the Arctic Ocean showing Long Strait and the general pattern of currents (after USNHO 1958).

During the oceanographic cruise of the USS Burton Island (AGB-1) in the summer of 1966, about 440 current measurements were made in Long Strait with Ekman-type current meters. This is the most comprehensive suite of current data yet collected from the area and reveals significant information about the nature and generation of the currents in the strait.

It seems fairly well established (Aagaard and Coachman 1964) that during summer in both the East Siberian and Chukchi seas, there is an eastward current along the Siberian coast known as the Chukchi Current (Gorbunov 1957) or the Siberian Coastal Flow (Aagaard 1964). Such a movement of water, taking place on either side of the strait, suggests that there must be a southeastward current through Long Strait. However, most investigators, lacking adequate information for such a firm conclusion, have felt that the current regime was probably not so simple.

Sverdrup (1929), in the report of the Maud expedition, showed a schematic representation of the currents in the East Siberian Sea which included a suggestion of westward flow near the bottom in Long Strait.

Gorbunov (1957) reported the conclusion of earlier Russian workers that there was a southeast-setting cold current along the Siberian coast, with a countercurrent of Chukchi Sea water moving westward along southern Wrangel Island. This countercurrent curved south in the strait to join the cold current. The U.S. Navy Hydrographic Office (1958) assumed much the same situation (Fig. 1), giving an estimate of 0.3 to $1 \mathrm{knot}\left(15\right.$ to $50 \mathrm{~cm}$. $\left.\mathrm{sec}^{-1}\right)$ for the current setting eastward through the strait.

Aagaard (1964), on the basis of extensive water-mass analysis, stated that "a Siberian coastal flow does set southeastward at least part of the year." He felt 
that this was necessary to account for the relatively dilute water found near the mainland coast eastward of Long Strait. On the other hand, in 1960 many drift bottles were released in the vicinity of Bering Strait (Fleming and Heggarty 1962). During the summer of 1961, there were 6 returns from Siberia: 1 from southern Wrangel Island, 1 from the mainland east of Long Strait, and 4 from the mainland west of Long Strait. The most reasonable path the bottles may have travelled suggests that there is sometimes a westbound flow through the strait.

Gorbunov (1957) presented results from several recent investigations in Long Strait. He reported data from 6 current-measurement stations across the strait, 3 stations each in late August of 1952 and of 1953. Details of the procedures and data were not given, but he reported essentially uniform westward velocities across the width and depth of the channel in both years. During all measurements, the winds were from the east and southeast.

A radio beacon was placed on the ice on 15 May 1956 and was tracked throughout the summer until the signal stopped on 20 September. During the 4 months of operation, the marker followed the path shown in Fig. 2. Gorbunov found a good correlation between the beacon's speed and the percentage of time the wind blew with a westerly velocity component during several periods of steady movement (Fig. 2, inset).

Gorbunov concluded that a uniform flow pattern is developed in either direction through the strait in response to steady winds in that direction. If the winds are weak or variable, the situation is more complicated.

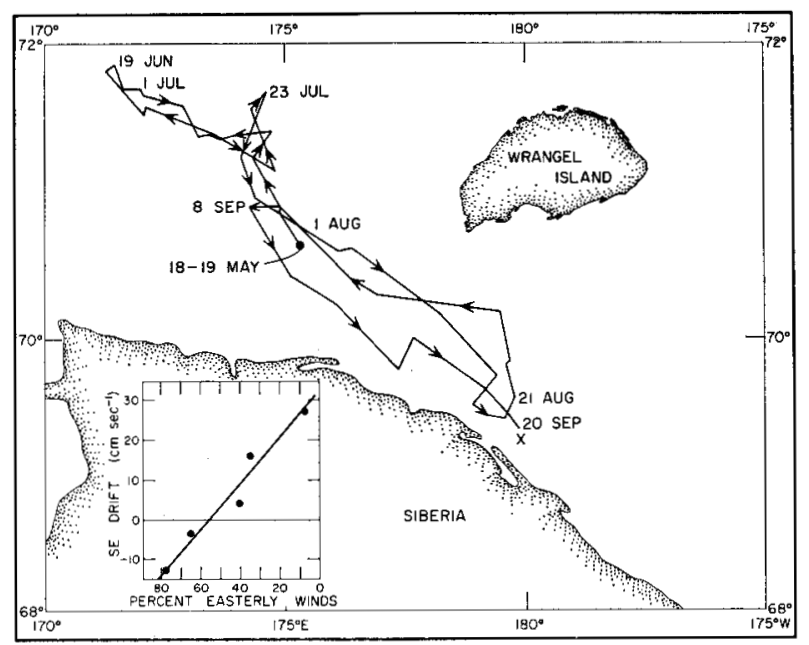

FIG. 2. Drift of radio beacon in Long Strait, summer 1956. Inset: correlation between beacon speed and wind for periods of steady movement (after Gorbunov 1957).

The Burton Island left Seattle on 20 July 1966 for an oceanographic cruise in the Chukchi Sea. The first observations were made on 30 July just north of Kolyuchin Bay (Fig. 1, and Fig. 3, inset). After several days in that area, operations were moved to Long Strait, where stations were occupied until 24 August (Fig. 3). All times and dates are based on the $165^{\circ} \mathrm{W}$. longitude time zone (+11 time: Bering Standard Time). 


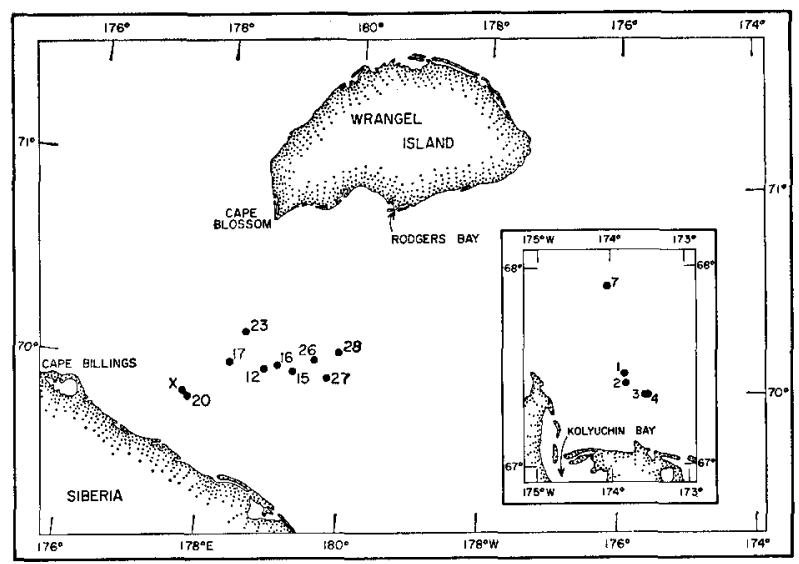

FIG. 3. Location of Burton

Island stations in Long Strait and (inset) off Kolyuchin

Bay.

Each station consisted of water-sampling and current measurements from anchor. Hydrographic data were taken about every 4 hours and current observations were made as often as possible. The hydrographic data were obtained and processed in the standard manner and will be published by the U.S. Naval Oceanographic Office.

The current measurements were made with Ekman-type meters and are reported in Rankin (1967). Each measurement was a 5- to 10-minute average of speed and direction at a given depth. The threshold of reliable meter response is considered to be $2 \mathrm{~cm}$. $\mathrm{sec}^{-1}$.

The meters have magnetic compasses to determine the direction; owing to the magnetic influence of the ship, which drew about 9 to $10 \mathrm{~m}$, the recorded directions above $15 \mathrm{~m}$. were considered unreliable. Under good light conditions, it was possible to make a visual observation of the meter down to a depth of about $10 \mathrm{~m}$., which was correlated with the ship's lead. The directions are considered reliable to $\pm 10^{\circ}$.

Excessive motion of the meter can induce errors in current measurements. On two occasions, it was necessary to terminate or disregard some measurements toward the end of the station because of excessive rolling.

\section{RESULTS AND DISCUSSION}

The measurements are presented graphically in Fig. 4, in which the abscissa spans the time of operations in the strait, and the ordinate indicates the depth. Each measurement is placed on the figure as a vector representing the current speed (see scale) and direction (north oriented along ordinate) with its origin at the appropriate time-depth intersect. In those cases in which the direction is unknown, the speed is represented by a vertical line proportional in length to the speed.

Inspection of the data reveals that the time dependence of the current velocities in Long Strait is quite complex, and indeed appears almost random. However, the pattern is somewhat simplified if the flow is considered in terms of components toward true $030^{\circ}$ (cross-channel) and $120^{\circ}$ (along-channel) and in two aspects: a regular oscillation of the semidiurnal period and longer term aperiodic changes in the mean flow. 

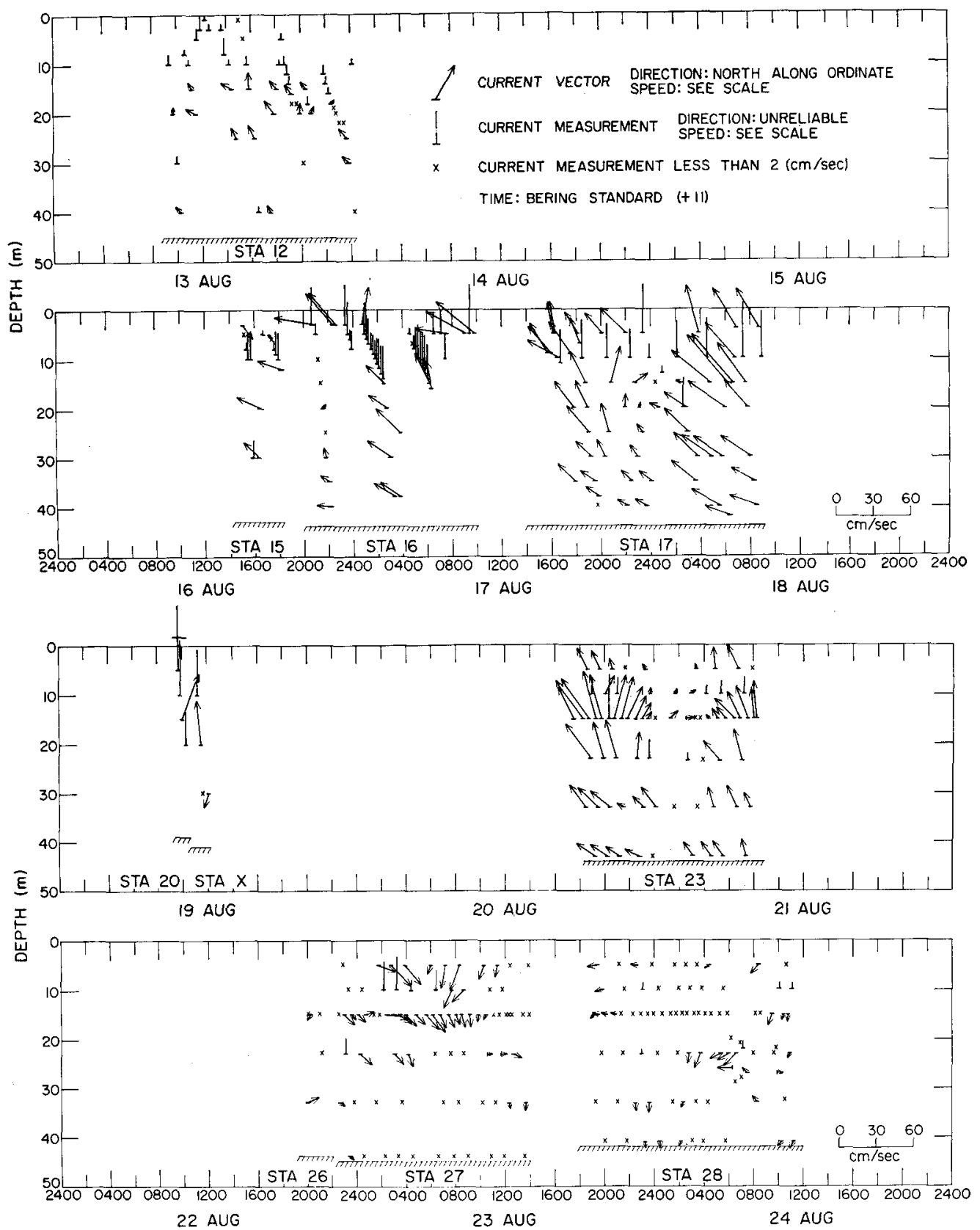

FIG. 4. Current observations from Long Strait in August 1966.

At two different times, Gorbunov (1957) observed the same basic current pattern across the strait. Therefore, over the relatively narrow cross-channel range of the stations made from the Burton Island (Fig. 3), the mean water movement should be much the same at the various stations and any tidal phenomenon would produce at most a slight change in phase of current oscillation. Finally, the marked variations in the currents can be much more satisfactorily explained as changes 
with time rather than changes in position. Hence, in this analysis, possible current variations due to different station locations have been disregarded.

\section{Semidiurnal Oscillations}

The observed periodicity could be due to semidiurnal tidal (12.48-hour period) or inertial (12.74-hour period at $70^{\circ}$ latitude) motion. Investigation shows strong evidence of a tidal origin for this oscillation.

The tides in the Arctic Ocean are primarily semidiurnal and almost entirely due to the northward propagation of the Atlantic Ocean tide (Defant 1961). In Long Strait, the motion of the crest of the tidal wave is apparently oblique to the Siberian coastline, with components onshore and eastward through Long Strait (U.S. Navy Hydrographic Office, 1958). Fig. 5 shows the tidal curve for Rodgers Bay, Wrangel Island, as predicted by the U.S. Coast and Geodetic Survey Tide Tables for 1966. While it is not certain how well the tidal constants are known, the curve should be at least qualitatively correct. The tides are quite uniformly semidiurnal with a fortnightly variation from a neap range of less than $1 \mathrm{ft}$. to a spring range of nearly $3 \mathrm{ft}$.

Comparison of the $120^{\circ}$ (along-channel) components of the currents with the predicted tide at Rodgers Bay reveals a regular temporal relationship between the tides and currents (Figs. 6 to 9). Throughout the record, the peak easterly (or least westerly) speeds occurred during rising tides and the maximum westerly speeds occurred during falling tides. According to the tide table, the tide on the mainland occurs about 1.7 hours after that at Rodgers Bay; thus, in the area of measurement, the tides might occur about an hour later than shown. But this possible change in timing does not affect the essence of the situation, namely, that the observed oscillation is regularly repeated, maintains the same phase relationship to the tidal curve, and agrees in timing with what would be expected for a tidal wave progressing eastward through the strait.

The amplitude of the oscillation varies widely at different stations. It is large and definite at Stations 17 and 23 (Figs. 6 and 7), yet becomes smaller and somewhat masked by more erratic behaviour (noise) at other times, such as at Stations 27 and 28 (Figs. 8 and 9). This is partly the result of short records and scanty data at some of the stations, but a more fundamental cause is fortnightly variations in tidal range. Fig. 10 plots the tidal range and the approximate range of

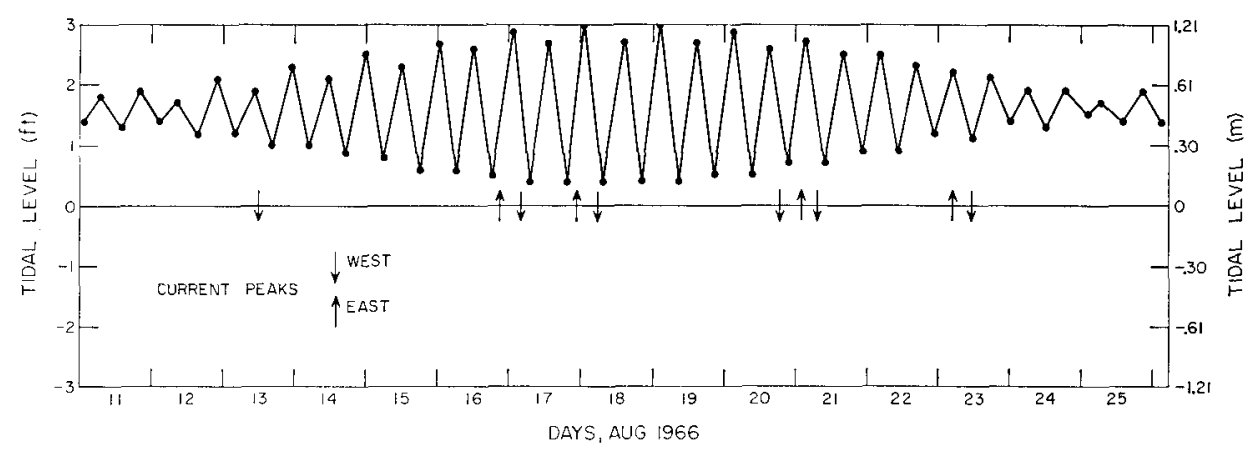

FIG. 5. Tide at Rodgers Bay, Wrangel Island, 11 to 25 August 1966 (USC\&GS Tide Tables). 


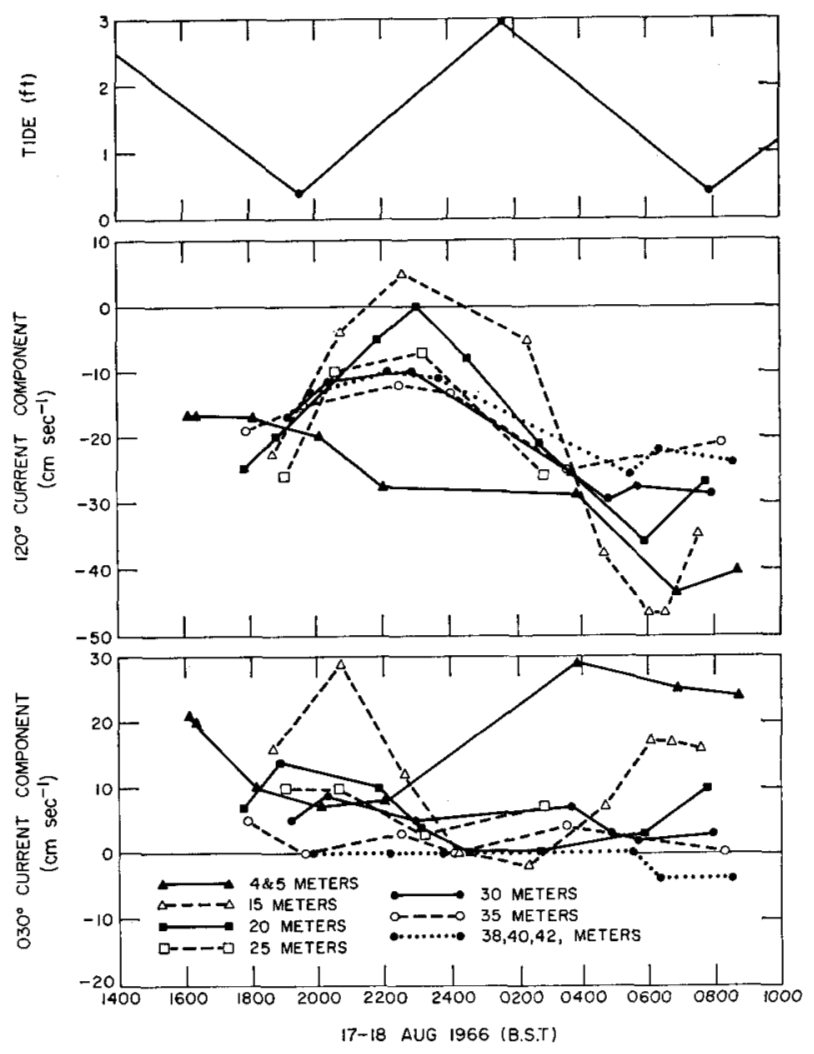

FIG. 6. Tide at Rodgers Bay and $120^{\circ}$ and $030^{\circ}$ current components for Station 17, 17 to 18 August 1966.

oscillation of the $20-$ to $25-\mathrm{m}$. depth $/ 120^{\circ}$ current component. This figure demonstrates, within the limitations of the data, a linear dependence between the two.

Figs. 6 to 9 also show the $030^{\circ}$ (cross-channel) components. Oscillations, while observable in some of the records, are less definite in period and phase than those of the along-channel components, and show significant changes with depth. The relative weakness of the cross-channel motion suggests that the tidal wave propagates primarily along the axis of the strait with only secondary lateral oscillations.

\section{Long-Period Changes}

The drift of the Russian ice-mounted radio beacon showed several major reversals in direction of movement (Fig. 2). Similarly, during the time of the Burton Island observations, there were one or more such changes in the flow pattern. Early in August, while the Burton Island was operating in the vicinity of Kolyuchin Bay, the local currents were predominantly to the east and south. In addition, there seemed to be a modification of the ice distribution, with a large flux of ice moving southeastward along the coast and filling in previously open areas north and west of Kolyuchin Bay. Thus, there may have been an eastbound current through Long Strait at that time. The first measurements in the strait, taken 13 August (Station 12), revealed a westbound current. Though of varying speed, currents at all stations through 21 August (Station 23) showed continued westward flow. On 22 and 23 August (Stations 26 and 27) there was an eastbound 

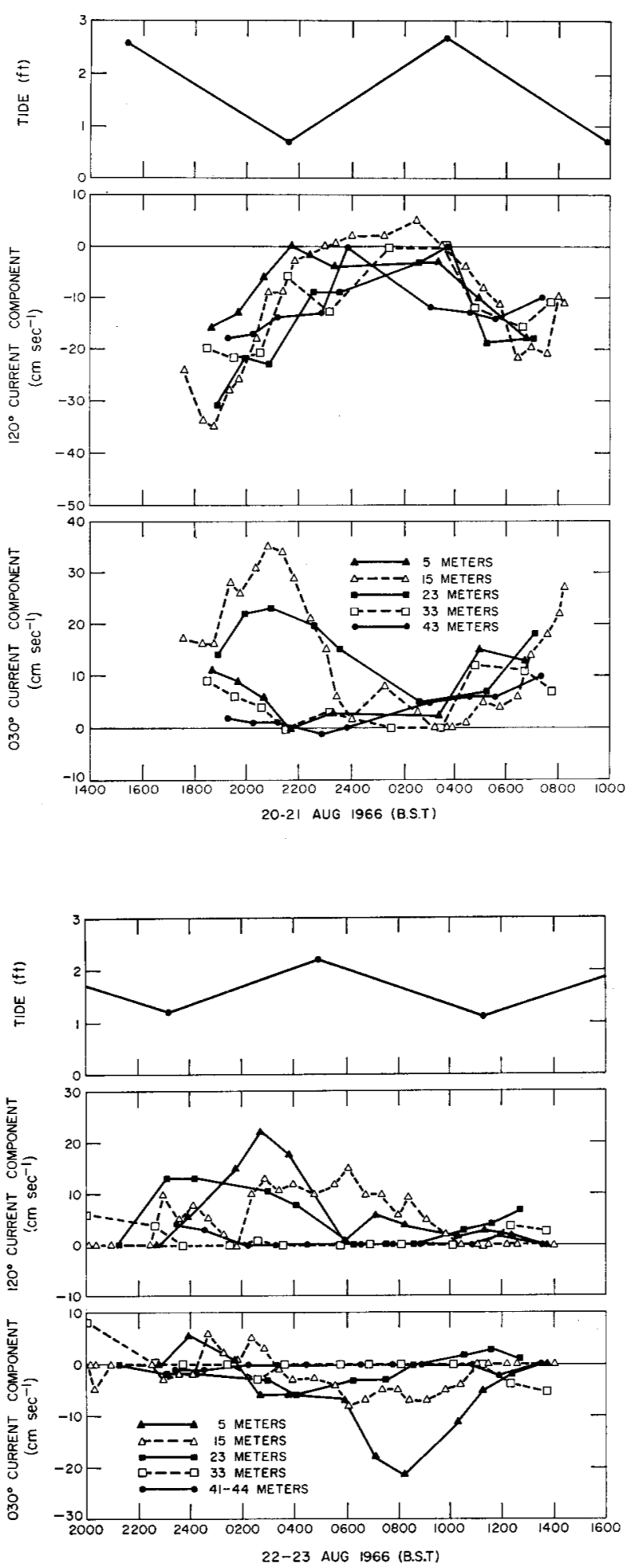

FIG. 7. Tide at Rodgers Bay and $120^{\circ}$ and $030^{\circ}$ current components for Station 23, 20 to 21 August 1966.
FIG. 8. Tide at Rodgers Bay and $120^{\circ}$ and $030^{\circ}$ current components for Station 27, 22 to 23 August 1966. 


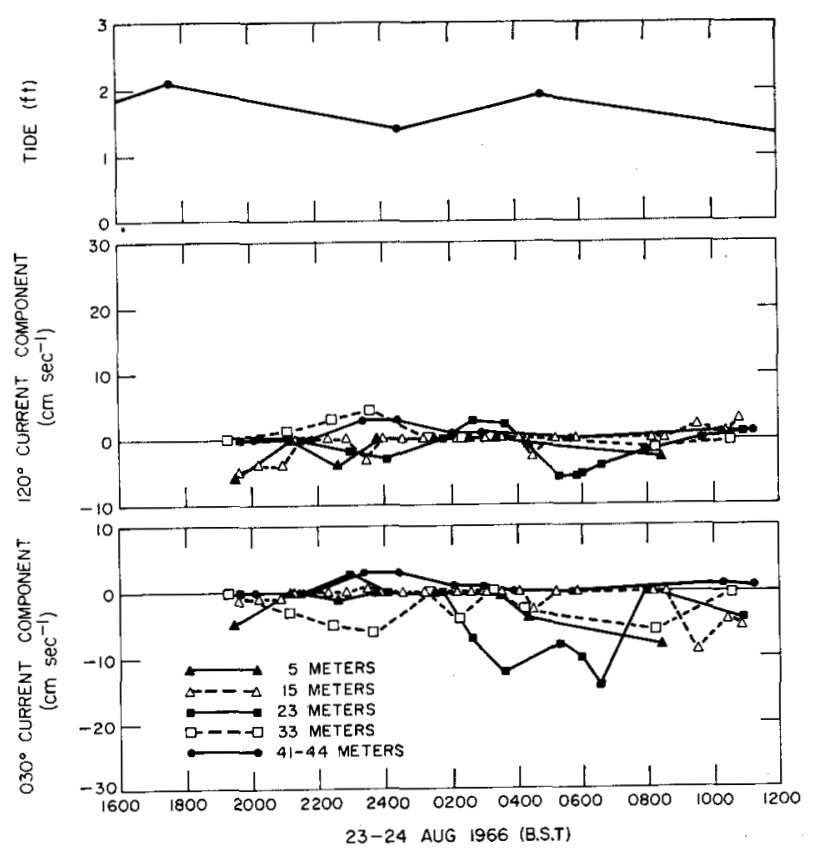

FIG. 9. Tide at Rodgers Bay and $120^{\circ}$ and $030^{\circ}$ current components for Station 28 , 23 to 24 August 1966.

upper layer over a quiet lower layer. The next day (Station 28) there was no net movement.

Fig. 11 shows mean values of the $120^{\circ}$ component at 20 to $25 \mathrm{~m}$. depth and the local wind velocities during the 12 days of observations. Gorbunov (1957), using fairly long-term averages, found good agreement between ice movement and local surface winds. The present data, however, indicate that the mean flow is less directly related to the local wind. The current continued to run westward after a long period of strong westerly winds into 17 August. The reversal of the

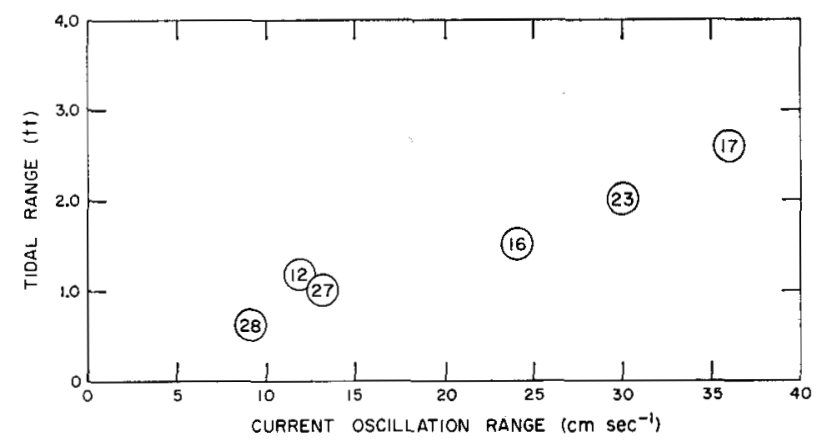

FIG. 10. Tidal range at Rodgers Bay vs. range of oscillation of 20 - to $25-\mathrm{m}$ depth $/ 120^{\circ}$ current component.

mean flow from west to east, first observed on 22 August, came after a fairly short period of light west winds. While there is no doubt that the local winds do affect ice and surface-water movement, as was evidenced by the $5-\mathrm{m}$. depth current at station 17 (Fig. 6), it is necessary to look to larger, area-wide conditions to find an adequate explanation of the changes in mean flow. 
Fig. 11 also plots the atmospheric pressure differential between a weather station on western Wrangel Island and stations at Barrow, Alaska, and the Kolyma River delta (see Fig. 1). These data were obtained from twice-daily U.S. Weather Bureau surface-weather maps of the northern hemisphere. The curves, plus a consideration of geostrophic winds, suggest a plausible explanation for the changes in mean flow. During the period 13 to 18 August, there was a major pressure differential between Wrangel Island and Point Barrow, the pressure at Wrangel Island being higher. Thus, across the Chukchi Sea, the net wind was directed south with a resulting surface stress to the south and movement of water to the southwest. Since Bering Strait apparently has a unidirectional northward flow during summer (Coachman and Aagaard 1966), the geometry of the Chukchi Sea is such that the westward flow through Long Strait appears to have been dictated by continuity requirements.

A similar stimulus to westward motion until 22 August is indicated by the pressure differential between the Kolyma River delta station to the west and Wrangel Island. The pressure at Wrangel was higher, which indicates a southerly wind and water transport away from the Siberian coast. While the geometry is less restrictive in the East Siberian Sea, the continued westward flow may again be reasonably attributed to regional continuity requirements. During 22 to 24 August, both the pressure differences and the mean currents were weak, a situation which agrees with the hypothesis formulated above.

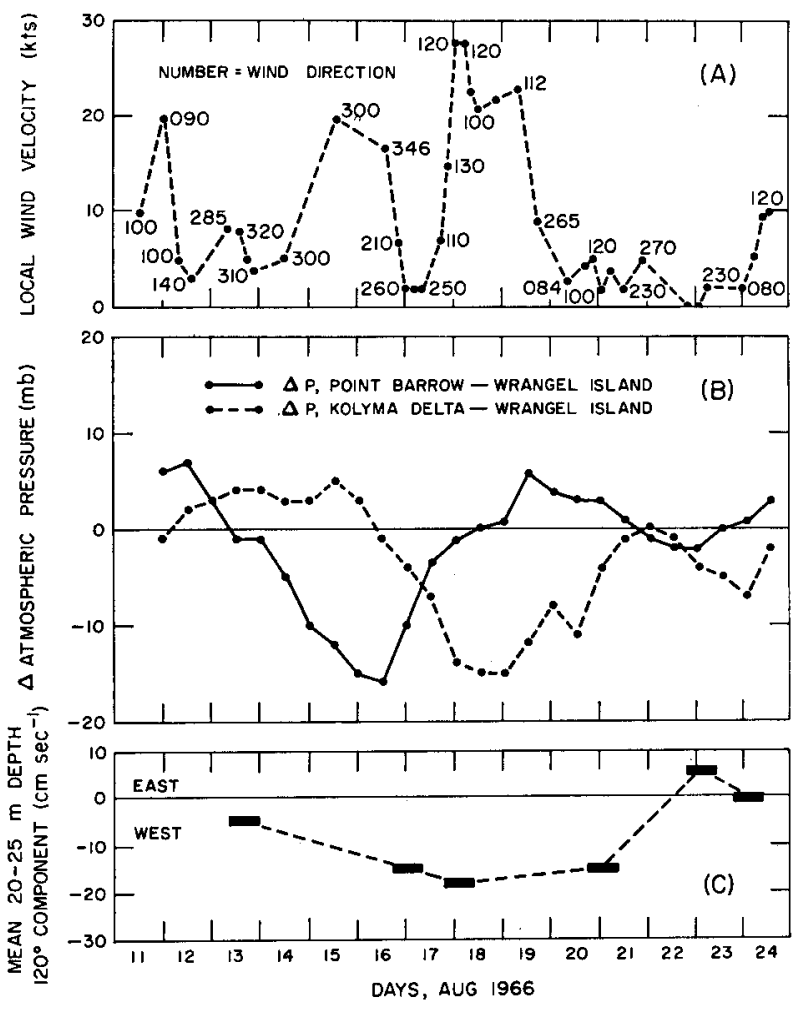

FIG. 11. Local wind, regional pressure differences, and mean axial current in Long Strait for 11 to 24 August 1966: (A) winds recorded on Burton Island; (B) differences in surface atmospheric pressure between Wrangel Island and stations to the east (Point Barrow) and west (Kolyma River delta); (C) mean over a tidal cycle of 20 - to $25-\mathrm{m}$ depth $/ 120^{\circ}$ current component for significant stations. 


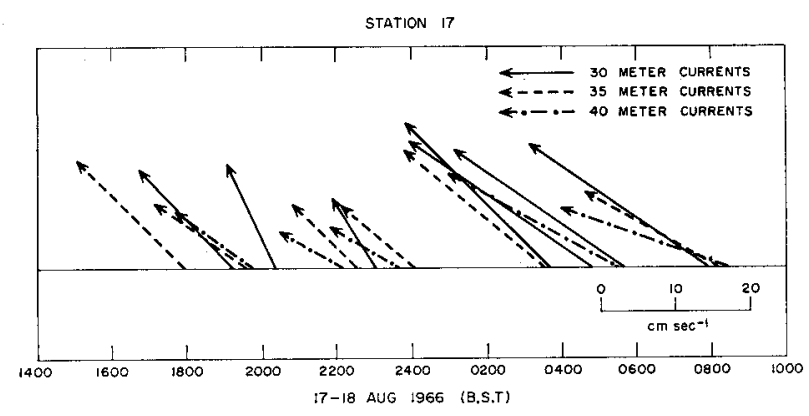

FIG. 12. Vectors of currents at intervals above the bottom, Stations 17 and 23 .

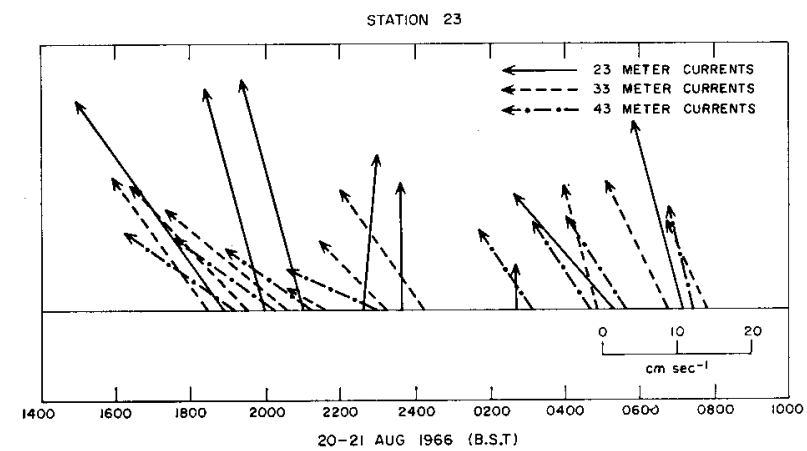

\section{Depth and Boundary Effects}

The observed currents showed some depth dependence and effects of surface and bottom boundaries. The $030^{\circ}$ components behaved as expected for a twolayer system, with lower speeds and less fluctuation below the pycnocline (Figs. 6 to 9), which usually lay at a depth of between 10 and $20 \mathrm{~m}$. The amplitude of the $120^{\circ}$ current oscillations shows a regular decrease with depth, the value at $1 \mathrm{~m}$. off the bottom being about half that at $15 \mathrm{~m}$. (Figs. 6, 7, and 8). The current also decreased slightly with depth.

At least two boundary effects were observed. Stations 17 and 23 (which had fairly high mean velocities) showed evidence of a bottom Ekman spiral. In agreement with theory (Proudman 1953), the velocity vectors decreased and turned to the left as the bottom was approached. This effect is depicted in Fig. 12, where the measured currents at intervals up from the bottom are plotted as vectors with north along the ordinate.

During Station 17, there was a noticeable effect of the wind on the surfacewater motion. Around 2000 hours on 17 August, a storm front moved over the ship and the wind rapidly rose above 20 knots $\left(10 \mathrm{~m} . \mathrm{sec}^{-1}\right)$ from about $120^{\circ}$. In response, a surface current to the northwest obscured the expected tidal oscillation at the 5-m. level (Fig. 6).

\section{CONCLUSIONS}

A relatively complex pattern of currents was measured in Long Strait during August 1966. A combination of several governing factors and modifying influences can account quite satisfactorily for the observed currents: 
1) The semidiurnal tide wave of the Arctic Ocean propagates eastward through Long Strait. There is a significant tidal oscillation of the currents along the axis of the channel, which varies in amplitude with the semimonthly tidal inequality.

2) There are some cross-channel oscillations, probably in part a result of tidal motion but without a clearly defined generating mechanism.

3) The long-term mean flow through the channel seems to be determined by the continuity requirements of the Chukchi Sea-East Siberian Sea system as it responds to the regional winds. When the regional atmospheric pressure gradients dictate southerly winds east of Wrangel Island and/or northerly winds to the west, there is a mean westbound flow through Long Strait, and vice versa. At any particular time, the mean flow may move against the local winds. The ice field and surface-water layer respond more sensitively to local winds.

4) Examples of the wind effect on surface-water motion and bottom Ekman spirals were observed.

\section{ACKNOWLEDGEMENT}

This paper constitutes Contribution No. 438 from the Department of Oceanography, University of Washington. The work was supported by contracts with the Office of Naval Research, Department of the Navy (Nonr-477(37), Project NR 083 012), and the Arctic Institute of North America.

\section{REFERENCES}

AAGAARD, K., 1964. Features of the physical oceanography of the Chukchi Sea in autumn. M.S. thesis, University of Washington, $28 \mathrm{pp}$.

AAGAARD, K., and L. K. COACHMAN, 1964. Notes on the physical oceanography of the Chukchi Sea. U.S. Coast Guard Oceanographic Report, No. 1, pp. 13-16.

COACHMAN, L. K., and K. AagaARD, 1966. On the water exchange through Bering Strait. Limnology and Oceanography, 11(1): 44-59.

Defant, A., 1961. Physical Oceanography. Vol. II. London: Pergamon Press, 590 pp.

FLEMING, R. H., and D. HEGGARTY, 1962. Recovery of drift bottles released in the southeastern Chukchi Sea and northern Bering Sea. University of Washington, Department of Oceanography Technical Report 70, 18 pp.

GORBunov, Y. A., 1957. On the water exchange between East Siberian and Chukchi Seas through the Straits of Long. Problemy Arktiki, No. 1, pp. 35-40. (Transl.)

Proudman, J., 1953. Dynamical Oceanography. London, Methuen \& Co., 401 pp.

RANKIN, D. A., 1967. Current measurements from Long Strait, summer 1966. University of Washington, Department of Oceanography Technical Report 188 (in press).

SVERDRUP, H. U. 1929. The waters on the North Siberian shelf. The Norwegian North Polar Expedition with the Maud (1918-1925). Scientific Results. Vol. IV, No. 2, 131 pp.

U.S. NAVY HYDROGRAPHIC OFFICE. 1958. Oceanographic atlas of the Polar Seas, Part I1, Arctic. Hydrographic Office publication number 705, $139 \mathrm{pp}$. 